\title{
Şanlıurfa yöresi asitli hastaların değerlendirilmesi
}

\author{
Evaluation of patients with ascites in the Şanlıurfa Region
}

\author{
Ahmet UYANIKOĞLU1', Hüseyin DURSUN², Çiğdem CINDOĞLU², Hacer UYANIKOĞLU³, Necati YENICE ${ }^{1}$ \\ Harran Üniversitesi, Tıp Fakültesi, 'Gastroenteroloji Bilim Dalı, ${ }^{2}{ }_{\text {ç }}$ Hastalıkları Anabilim Dalı, ${ }^{3}$ Kadın Doğum Anabilim Dalı, Şanlıurfa
}

Giriş ve Amaç: Asit tetkik nedeniyle takip edilen hastaların demografik, klinik, laboratuvar ve etiyolojik özelliklerinin araştırılması amaçlanmıştır. Gereç ve Yöntem: Araştırmaya Ocak 2013- Ekim 2014 döneminde ilk defa asit tespit edilen veya daha önce tanı konulan, dosyalarında yeterli veri bulunan hastalar dahil edilmiştir. Bulgular: Gastroenteroloji kliniğine asit tetkik nedeni ile yatırlan veya takip edilen 142 hastanın 65'i (\%46) erkek, yaş ortalaması 58.4 16 yaş (dağılım 16-89) idi. Hastaların 114 'ünde (\%80) portal asit, 28 'inde (\%20) non portal asit saptandl. Tüm asit nedenlerinde (\%68) ve portal tip asitte (\%85) en sık neden karaciğer sirozu idi. Sirotik hastalardan 3 tanesinde hepatosellüler kanser, 1 tanesinde B hücreli lenfoma saptandı. Diğer portal tip asit nedenleri; 4 kardiyojenik, 4 kronik böbrek yetmezliği, 3 hasta Budd-Chiari, 2 kısa barsak sendromuna bağlı hipoalbüminemi, 1 portal tromboz, 1 hipotroidi, olarak saptandi. Non portal tip asit nedenleri ise 10 hastada (\%7) primeri belli olmayan peritoneal karsinomatoz, 6 (\%4) over kanseri, 5 (\%3) tüberküloz peritonit, 2 mide kanseri, birer hastada periampüller kanser, kist hidatik rüptürü, endometrium kanseri, nefrotik sendrom ve ameliyat sonrası safra kaçağına bağı asit idi. Sonuç: Asitli hastaların yaklaşık \%80'i portal hipertansif tip asit olup tüm asit nedenleri ve portal hipertansif asitte en sık neden sirozdur. Non portal asitte en sık neden malignite olup hastaların yaklaşık üçte ikisinden sorumlu, ikinci en sık neden ise tüberküloz peritonit idi.

Anahtar kelimeler: Asit, siroz, malignite, tüberküloz

\section{GíRiș}

Asit peritoneal kavitedeki anormal sıvı birikimidir. Normal olarak periton boşluğunda diğer seröz boşluklarda olduğu gibi az miktarda (<50 ml) ve yüksek proteinli (4 gr/ dl) bir sıvı vardır. Periton boşluğunda normalden fazla, patolojik miktarlarda sıvı birikmesine asit, bu sıvıya ise asit sıvısı denir. Asit sirozun en sık görülen komplikasyonudur ve asit birikmesine en sık yol açan karaciğer hastalığı sirozlardır $(1,2)$.

Fizik muayeneyle asiti saptayabilmek için periton boşluğunda en az 1500 mililitre (mL) kadar sıvı bulunması gerekmektedir, karında perküsyonla açıklığı yukarı bakan ve pozisyonla yer değiştiren matite saptanmaktadır. Ultrasonografi (USG) ile 100 mL'ye kadar olan karın içi sıvılar

Iletişim: Ahmet UYANIKOĞLU

Harran Üniversitesi, Tıp Fakültesi, Gastroenteroloji Bilim Dalı, Şanlıurfa E-mail: auyanikoglu@hotmail.com

Not: 10. Ulusal Hepatoloji Kongresinde sözlü bildiri olarak sunulmuştur. 27-30 Mayıs 2015, istanbul, SB-010, 134
Background and Aims: This study aimed to evaluate patients with ascites who were followed to investigate their demographic, clinical, laboratory, and etiological features. Materials and Methods: The study was conducted from January 2013 to October 2014, and included patients with ascites that was detected for the first time before or diagnosed during this period. Patients with sufficient data in their files were included. Results: Examinations were conducted by the gastroenterology clinic because of ascites. This study included 142 patients, 65 (46\%) were male and had a mean age of $58.4 \pm 16$ years (range, 16-89 years). Also, 114 patients (80\%) had portal ascites, whereas 28 (20\%) had non-portal ascites. All-cause ascites (68\%) and portal-type ascites (85\%) were the most common causes of liver cirrhosis. Three cirrhotic patients had hepatocellular carcinoma and B cell lymphoma was detected in 1 patient. Other causes of portal ascites were cardiogenic in 4 patients, chronic kidney failure in 4 patients, Budd-Chiari in 3 patients, short bowel syndrome due to hypoalbuminemia in 2 patients, portal vein thrombosis in 1 patient, hypothyroidism in 1 patient. Causes of non-portal type ascites were in peritoneal carcinomatosis 10 patients (7\%), ovarian cancer in 6 patients (4\%), peritoneal tuberculosis in 5 patients (3\%), gastric cancer in 2 patients, one in a patient with periampullary cancer, cyst rupture, endometrial cancer, nephrotic syndrome and postoperative biliary leakage was ascites. Conclusion: Approximately $80 \%$ of patients with ascites have portal hypertensive-type ascites. It is the most common cause of both cirrhosis and portal hypertension. Non-portal ascites is the most common malignancy and occurs in about two-thirds of patients, whereas the second reason is peritoneal tuberculosis.

Key words: Ascites, cirrhosis, malignancy, tuberculosis

saptanabilmektedir (3). Sadece tetkik için değil, terapötik amaçı parasentez de yapılmaktadır (4-6).

Nedeni ne olursa olsun, asit ilk saptandığında her olguda parasentez yapılarak tetkik edilmelidir. Asit nedeni, \%8085 olguda karaciğer sirozu iken, diğer olgularda non-hepatik nedenler saptanmaktadır. Asit, karaciğer sirozunun en sık görülen majör komplikasyonu olup, kompanse sirozlu hastaların ortalama yarısında 10 yıllık bir takip süresi içinde ortaya çıkmaktadır. Asit geliştikten sonra iki yıllık sağ kalım oranı ortalama \%50 civarındadır (7-9).

Serum ve asit albümin konsantrasyonları arasındaki farkın [albümin gradienti veya serum asit albümin gradienti (SAAG)] doğrudan kolloid osmotik basınç gradientini ve

Uyanıkoğlu A, Dursun H, Cindoğlu Ç, et al. Evaluation of patients with ascites in the Sanlıurfa Region. The Turkish Journal of Academic Gastroenterology 2019;18:23-26. DOI: 10.17941/agd.544712

Geliş Tarihi: 30.03.2016 • Kabul Tarihi: 27.12.2016 
dolaylı olarak portal hipertansiyon derecesini yansıttığı düşünülmektedir (10). Pare ve arkadaşları SAAG'nin asit protein konsantrasyonuna göre portal hipertansiyonun daha iyi bir ayırımcısı olduğunu ileri sürmektedir (11). SAAG'i, asit çalışmaları içerisinde daha faydalı fizyolojik ve klinik araç olarak görülmektedir (12).

Etiyolojide ne düşünülürse düşünülsün yeni saptanan her asit olgusunda asit sıvısı ponksiyone edilerek gerekli incelemeler yapılmalıdır $(4,10,11)$. Diğer yandan, özellikle sirotik asiti olduğu bilinen hastalarda klinik tablonun değişmesi durumunda, olası spontan bakteriyel peritonit ya da malignite göz ardı edilmemelidir (7).

Bu çalışmada son 2 yılda asit tetkik nedeniyle takip edilen hastaların demografik, klinik, laboratuvar ve etiyolojik özelliklerinin araştıııması ve literatürle karşılaştırıması amaçlanmıştır.

\section{GEREÇ ve YÖNTEM}

Araştırmaya Ocak 2013- Ekim 2014 döneminde ilk defa asit tespit edilen veya daha önce tanı konulan, dosyalarında yeterli veri bulunan hastalar dahil edilmiştir, çalışma retroprospektiftir. Bu hastaların demografik, klinik ve laboratuvar özellikleri incelenmiştir.

Tüm hastaların ayrıntılı anamnezleri alındı, fizik muayeneleri yapılarak rutin biyokimyasal analizler yapıldı. Asit tanısı fizik muayene, batın USG ile konuldu ve parasentez uygulandı (1). Parasentez ile alınan asit sıvısı biyokimyasal, mikrobiyolojik ve sitolojik olarak incelendi. Gereken hastalara USG dışında batın bilgisayarlı tomografisi, batın magnetik rezonans görüntüleme, pozitron emisyon tomografisi gibi ileri görüntüleme yöntemleri ve laparoskopi, laparoskopik biyopsi yapıldı.

Asit sıvısının biyokimyasal incelemesi ile serum ve asit albümin konsantrasyonları arasındaki fark (SAAG) hesaplanarak asitli hastalar portal hipertansif tipte olanlar ve olmayanlar olmak üzere iki ana grupta incelendi. Gereken hastalarda asit sıvısında sitoloji, hücre sayımı, adenozin deaminaz (ADA), bilirübin, amilaz vb ek tetkikler yapıldı $(4,11-13)$.

\section{BULGULAR}

Gastroenteroloji kliniğinde asit tetkik nedeni ile takip edilen 142 hastanın 65'i (\%46) erkek, 77'si kadın (\%54), yaş ortalaması $58.4 \pm 16$ yaş (dağıım 16-89) idi. Hastaların $114^{\prime}$ ünde (\%80) portal asit, $28^{\prime}$ inde (\%20) non portal asit saptandı (Tablo 1). Her iki hasta grubunda yaş, cinsiyet dağılımı arasında fark yoktu $(p>0.5)$. Tüm asit nedenlerinde (\%68) ve portal tip asitte (\%85) en sık neden karaciğer sirozu idi.
Portal hipertansif tip asit nedeni olan hastaların $\% 85^{\prime}$ inde etiyolojik neden siroz idi ve siroza neden olan hastalıklar 29 (portal tip asitli hastaların \%25'i) kriptojenik siroz, 29 (\%25) hepatit B, 25 (\%22) hepatit C, 7 (\%6) Delta hepatiti, 3 Wilson (\%3), 2 HVB-HCV koinfeksiyonu, birer alkole bağlı siroz, primer biliyer siroz (PBS), otoimmün hepatit, hemokromatoz idi. Sirotik hastalardan 3 tanesinde hepatosellüler kanser, 1 tanesinde B hücreli lenfoma saptandı. Diğer portal tip asit nedenleri (\%15) 4'er kardiyojenik, kronik böbrek yetmezliği (\%4), 3 hasta Budd-Chiari, 2 kısa barsak sendromuna bağlı hipoalbüminemi, 1 portal tromboz, 1 hiportoidi, olarak saptandı (Tablo 2).

Non-portal tip asit nedenleri ise 10 hastada (tüm hastaların \%7'si, non-portal asitlerin \%35'i) primeri belli olmayan peritoneal karsinomatoz, 6'sı (tüm hastaların \%4'ü, non-portal asitlerin \%21'i) over kanseri, 5'i (tüm hastaların \%3'ü, non portal asitlerin \%18'i) tüberküloz peritonit, 2 mide kanseri, 1 periampüller kanser, 1 kist hidatik rüptürü, 1 endometrium kanseri, 1 nefrotik sendrom, 1 hastada ise ameliyat sonrası safra kaçağı idi (Tablo 3). Tüberküloz asit tanısı laparoskopik olarak konuldu, malignite hastaları ilgili branşlara sevk edildi.

Tüm hastalarda ortalama albümin: $2.65 \pm 0.7$ (0.9-4.5), hemoglobin: $11.3 \pm 2.1(5.3-17) \mathrm{g} / \mathrm{dl}$ olup portal ve non-portal asitli hasta gruplarında benzerdi $(p>0.5)$.

Tablo 1. Tüm hastaların serum asit albümin gradientlerine (SAAG) göre dağılımı

\begin{tabular}{|lcc|}
\hline Asit Tip & N & $\%$ \\
\hline Portal hipertansif tip asit & 114 & $\% 80$ \\
\hline Non-portal hipertansif tip asit & 28 & $\% 20$ \\
\hline Toplam & 142 & $\% 100$ \\
\hline
\end{tabular}

Tablo 2. Portal tip asit saptanan 114 hastanın etiyolojik dağılımı

\begin{tabular}{|lcc|}
\hline Hastalık & N & $\%$ \\
\hline Siroz (toplam) & 99 & $\% 85$ \\
$\quad$ Kriptojenik siroz & 29 & \\
Hepatit B & 29 & \\
Hepatit C & 25 & \\
Delta hepatiti & 7 & \\
Wilson & 3 & \\
Diğer & 6 & \\
\hline Kardiyojenik & 4 & $\% 4$ \\
\hline Nefrotik & 4 & $\% 4$ \\
\hline Budd-Chiari & 3 & $\% 3$ \\
\hline Diğerleri & 4 & $\% 4$ \\
\hline
\end{tabular}


Tablo 3. Non-portal asit saptanan 28 hastanın etiyolojik dağılımı

\begin{tabular}{|c|c|c|}
\hline Hastalık & $\mathbf{N}$ & $\%$ \\
\hline Primeri belli olmayan peritoneal karsinomatoz & 10 & $\% 35$ \\
\hline Over kanseri & 6 & $\% 21$ \\
\hline Tüberküloz & 5 & $\% 18$ \\
\hline Mide kanseri & 2 & $\% 7$ \\
\hline Periampüller kanser & 1 & \\
\hline Emdometrium kanseri & 1 & \\
\hline Kist hidatik rüptürü & 1 & \\
\hline Nefrotik sendrom & 1 & \\
\hline Post-op safra kaçağı & 1 & \\
\hline
\end{tabular}

\section{TARTIŞMA}

Nedeni ne olursa olsun, asit ilk saptandığında her olguda parasentez yapılarak tetkik edilmelidir. Asit nedeni, \%85 olguda karaciğer sirozu iken, diğer olgularda non-hepatik nedenler saptanmaktadır (7). Bizim kliniğimizde de ilk asit saptandığında ve asit nedeni bilinse bile her yatışta mutlaka parasentez yapılarak tetkik yapılmaktadır. Asitli hasta serimizde de en sık asit nedeni olarak karaciğer sirozu saptanmıştır. Ancak serimizde literatüre göre daha düşük oranda, tüm asitli hastaların yaklaşık \%70'inde asit nedeni olarak siroz saptanmıştır.

Haseki Eğitim ve Araştırma Hastanesinde yapılan bir çaIışmada yaşları 15 ile 84 arasında değişen, yaş ortalaması 54.3 olan, 29' u erkek (\%50) ve 29'u kadın (\%50) olan 58 hasta incelenmiş. Hastaların $45^{\prime}$ inde (\%77.5) asit sıvısı portal hipertansif tipte, 13'ünde (\%22.5) non-portal hipertansif tipte saptanmıştır (14). Bizim hastalarımızda da yaş grubu, cinsiyet dağılımı ve portal, non portal tip asitli hasta oranları benzerdi.

İstanbul Tıp Fakültesi Gastroenteroloji Anabilim Dalında Çakaloğlu ve arkadaşları tarafından 1986-1995 yılları arasında, 9 yıllık asitli vakalar ile yapılan geniş serili çalışmada hastaların \%76'sında karaciğer sirozu, \%9.2'sinde peritoneal karsinomatoz, \%7.3'ünde tüberküloz etiyolojik neden olara bulunmuş. Benzer şekilde Runyon ve arkadaşları tarafından yapılmış olan geniş serili asit etiyoloji araştırmasında \%84 karaciğer sirozu, \%2.4 peritoneal karsinomatoz, \%0.7 tüberküloz etiyolojik neden idi. Bu iki çalışmayla karşılaştıııldığında bizim çalışmamızda da karaciğer sirozunun asit sıvısına neden olan en sık etiyolojik neden olduğu (tüm hastaların \%70'i), ancak her iki seriye göre daha az oranda etiyolojik neden olduğu, maligniteye bağlı asitlerin ise bizim çalışmamızda her iki seriye göre daha yüksek oranda olduğu saptandı. Tüberküloz peritonite bağlı asitli vakalar Çakaloğlu ve arkadaşlarının çalışmasına oranla belirgin olarak daha az saptanırken, Runyon ve arkadaşlarının çalışmasına göre belirgin yüksek saptandı $(\% 3)(2,15,16)$. Her iki seriyle kıyaslandığında bulgularımız bölgemizde maligniteye bağlı asit sıklığının artarken kıyaslanan çalışmaların eski olduğu dikkate alındığında geçmişe göre tüberküloz oranının düştüğü, ancak halen batıya göre daha sık ve önemli bir etiyolojik neden olduğu kanaatine vardık.

Suudi Arabistan'da 2 yıllık sürede 132 hastanın prospektif olarak incelendiği asit etiyoloji araştırmasında karaciğer sirozu en sık etiyolojik faktör olarak saptanmıştır. Aynı çalışmada maligniteye bağlı olarak gelişmiş olan asit sıvısı bizim çalışmamızla benzer oranlarda bulunmasına ră̆men tüberküloz peritonite bağlı asit sıvısı (\%10.6) bizim serimize göre 3 kat fazla bulunmuştur (17).

Yunanistan'da yapılmış olan 51 hastalık seride 32 hastada portal hipertansiyona bağlı (28 hastada siroz, 2 hastada kalp yetersizliği, 2 hastada Budd-Chiari sendromu), 19 hastada ise non-portal (17 hastada peritoneal karsinomatoz, 1'er hastada tüberküloz peritonit ve sekonder bakteriyel peritonit) karakterde asit saptanmıştır (18). Bizim serimize göre biraz daha sık non-portal asit ve malignite saptanırken daha az oranda siroz ve tüberküloz saptanmiştır.

Haseki Eğitim Hastanesi'nde yapılan çalışmada asit sıvısı etiyolojisi açısından değerlendirmesi yapılan 24 hasta ile karaciğer hastalıklarının en sık etiyolojik nedeni oluşturduğu, bu hastalardan 18'inde karaciğer sirozu (5'er hastada hepatit $B$ virüsüne, hepatit $C$ virüsüne ve alkole bağIı, 3 hastada kriptojenik karaciğer sirozu), 2'sinde kronik karaciğer hastalığı, birer hastada ise konjenital hepatik fibroz, primer biliyer siroz, otoimmün hepatit ve alkolik hepatit hastalıklarının asit sıvısına neden olduğu saptanmıştır (14). Bizim serimizde de en sık asit nedeni karaciğer hastalıkları olup, benzer şekilde en sık etiyolojik nedenler, hepatit $B$, hepatit $C$ ve kriptojenik siroz idi. Bu seriye göre kriptojenik oranımız biraz daha fazla iken, alkole bağlı asit saptadığımız tek hasta vardı ve bu seriye kıyasla daha az oranda idi. Kriptojenik sirozla ilgili yaptığımız başka bir çalışmada bu hastaların en az yarısının non alkolik steato hepatit (NASH) zemininde geliştiğini saptadık (19). Bölgemizde Türkiye'nin batısına göre daha az oranda alkole bağlı siroz ve asit görürken, daha fazla oranda NASH zemininde gelişen siroz ve asit görülmektedir.

58 hastalık aynı çalışmada 12 kişi ile çeşitli malignitelerin en sık 2. etiyolojik faktör, 11 kişi ile konjestif kalp yetersizliğinin 3. en sık etiyolojik faktör olarak rol aldığı 
saptanmıştır. 2 hastada tüberküloz görülmüştür (14). Bizim serimizde de non-portal asitin en sık nedeni olarak maligniteler saptanırken kalp yetmezliğine bağlı asit oranımız bu seriye göre düşük, tüberküloz oranımız benzerdir.

Özellikle sirotik asiti olduğu bilinen hastalarda klinik tablonun değişmesi durumunda, olası spontan bakteriyel peritonit ya da malignite göz ardı edilmemelidir (7). Bizim de sirotik hastalarımızdan 3 tanesinde hepatosellüler kanser, 1 tanesinde B hücreli lenfoma saptandı. Hastalarda siroz saptansa bile malignite açısından dikkatli değerlendirmek gerekir.

\section{KAYNAKLAR}

1. Serin E, Boyacıoğlu S. Siroz komplikasyonları ve tedavisi. In: Gastroenteroloji. Özden A, Şahin B, Yılmaz U, Soykan İ. (Eds) 1. Baskı. Fersa Matbaacılık, 2002: 528-532.

2. Ökten A, Mungan Z, Cakaloğlu Y, Boztaş G, Kaymakoğlu S, Beşışık F, Özdil S. Gastroenterohepatoloji. Nobel Tıp Kitapevleri, 2001: 345-368.

3. Kuiper JJ, van Buuren HR, de Man RA. Ascites in cirrhosis: a review of management and complications. Neth J Med 2007; 65: 283-8.

4. Biecker E. Diagnosis and therapy of ascites in liver cirrhosis. World J Gastroenterol 2011;17:1237-48.

5. Knudsen AW, Krag A, Nordgaard-Lassen I, et al. Effect of paracentesis on metabolic activity in patients with advanced cirrhosis and ascites. Scand J Gastroenterol 2016;51:601-9.

6. Gaetano JN, Micic D, Aronsohn A, et al. The benefit of paracentesis on hospitalized adults with cirrhosis and ascites. J Gastroenterol Hepatol 2016;31:1025-30.

7. Özdemir S. Cirrhotic ascites. Medical Journal of Bakırköy 2013;9:17.

8. Gines P, Quintero E, Arroyo V, et al. Compensated cirrhosis: natural history and prognostic factors. Hepatology 1987;7:122-8.

9. Kashani A, Landaverde C, Medici V, Rossaro L. Fluid retention in cirrhosis: pathophysiology and management. QJM 2008;101:71-85.

10. Hoefs JC. Serum protein concentration and portal pressure determine the ascitic fluid protein concentration in patients with chronic liver disease. J Lab Clin Med 1983;102:260-73.
Sonuç olarak Şanlıurfa yöresinde asit nedeniyle takip edilen hastaların yaklaşık \%80'i portal hipertansif tip asit olup tüm asit nedenleri ve portal hipertansif asitte en sık etiyolojik neden sirozdur. Bölgemizde siroza en sık neden olan hastalıklar hepatit $B$, hepatit $C$ ve kriptojenik sirozdur. Non-portal asitli hastaların yaklaşık üçte ikisinden sorumlu malignite en sık non-portal asit nedeni iken, tüberküloz ikinci en sık nedendir. Asitli her hasta öncelikle karaciğer sirozu yönünden araştırımalıdır. Sirozdan şüphelenilse bile maligniteler ve tüberküloz başta olmak üzere olası diğer nedenler de araştırılmalıdır.

11. Pare P, Talbot J, Hoefs JC. Serum ascites albumin concentration gradient: a physiologic approach to the differantial diagnosis of ascites. Gastroenterology 1983; 85: 240-244.

12. Hoefs JC. Diagnostic paracentesis: a potent clinical tool (editorial). Gastroenterology 1990;98:230-6.

13. Sola $E$, Sole $C$, Gines P. Management of uninfected and infected ascites in cirrhosis. Liver Int 2016;36(Suppl 1):109-15.

14. Meral CE, Karaali ZE, Yanmaz S, et al. Etiological distribution of ascites investigated patients. Med Bull Haseki 2005;43:0-0.

15. Çakaloğlu Y, Ökten A, Yaçın S. Serum ascites albümin concentration gradient (A-GRAD) in the prediction of of portal hypertension in ascitic patients. Gastroenterology 1991:100;1484-5.

16. Runyon BA, Practice Guidelines Committee, American Association for the Study of Liver Diseases (AASLD). Management of adult patients with ascites due to cirrhosis. Hepatology 2004;39:841-56.

17. Al-Knawy BA. Etiology of ascites and the diagnostic value of serum-ascites albumin gradient in non-alcohol liver disease. Ann Saudi Med 1997;17:26-8.

18. Akriviadis EA, Kapnias D, Hadjigavriel M, et al. Serum/ascites albumin gradient: its value as a rational approach to the differential diagnosis of ascites. Scand J Gastroenterol 1996;31:814-7.

19. Uyanıkoğlu A, Aydın F, Altunbaş R, et al. Siroz etiyolojisinde NASH'in yeri nedir? 12. Ulusal Hepato-Gastroenteroloji Kongre Kitabı. 8-10 Ekim 2015, Afyon, SB-10, 82. 